\title{
Enoyl-CoA Delta Isomerase 2, Mitochondrial
}

National Cancer Institute

\section{Source}

National Cancer Institute. Enoyl-CoA Delta Isomerase 2, Mitochondrial. NCI Thesaurus.

Code C113257.

Enoyl-CoA delta isomerase 2, mitochondrial (394 aa, $44 \mathrm{kDa}$ ) is encoded by the human $\mathrm{ECl} 2$ gene. This protein is involved in enoyl-CoA metabolism. 